\title{
RUNX1/ZNF687 Fusion Protein
}

National Cancer Institute

\section{Source}

National Cancer Institute. RUNX1/ZNF687 Fusion Protein. NCI Thesaurus. Code C99304.

A fusion protein encoded by the RUNX1/ZNF687 fusion gene. This protein is comprised of part of the $\mathrm{N}$-terminal runt domain of the runt-related transcription factor 1 protein fused to the entire zinc finger protein 687. 